\title{
REACTION OF SWEET PEPPER TO THE POTATO VIRUS Y (PVY'm $)^{1}$
}

\author{
Márcia de Moraes Echer2,4*; Cyro Paulino da Costa ${ }^{3}$ \\ ${ }^{2}$ Pós-Graduanda em Fitotecnia -USP/ESALQ. \\ ${ }_{4}^{3}$ Depto. de Produção Vegetal - USP/ESALQ - C.P. 9 - CEP: 13418-900 - Piracicaba, SP. \\ ${ }^{4}$ CAPES Fellow. \\ *Corresponding author<mmecher@bol.com.br>
}

\begin{abstract}
Traditional sweet pepper cultivars showing susceptibility to the Potato virus $Y$ (PVY) are being replaced by resistant hybrids with higher commercial value. Despite of much information about resistance source reaction and their inheritance, there is no knowledge about the genetic background of commercial resistant hybrids. Reaction of sweet pepper (Capsicum annuum L.) hybrids to the Potato virus Y (PVY ${ }^{\mathrm{m}}$ ) such as Acuario, Magali $R$, Nathalie and their respective generations $F_{2}$ and $F_{3}$ as well as hybrids Amanda, Corteso W208, CPC-6272, Dagmar, Elisa, Magali, Margarita, Monteiro, Quantum, Vivo W205 was evaluated. Reaction to $P V Y^{m}$ was evaluated as resistant or susceptible. Magali $R$ and Nathalie hybrid did not show any mosaic symptoms. Magali $\mathrm{R}$ and Nathalie hybrids resistance is due to a single dominant gene indicating resistant versus susceptible parental lines crossing pedigree. Amanda, Acuario, Corteso W208, Dagmar, Elisa, Margarita, Monteiro, Quantum and Vivo W205, considered resistant to PVY, were highly susceptibility to PVY strain m. Hybrids, claimed as resistant to the Pepper mottle virus (PepMoV), were also resistant to PVYm.

Key words: Capsicum annuum, resistance, potyvirus
\end{abstract}

\section{REAÇÃO DE PIMENTÃO AO POTATO VIRUS Y $\left(\mathrm{PVY}^{\mathrm{m}}\right)$}

\begin{abstract}
RESUMO: Cultivares tradicionais de pimentão que se mostravam altamente suscetíveis a Potato virus $Y$ (PVY) vêm sendo substituídas por híbridos com resistência e alto valor comercial. Apesar da reação e herança de muitas fontes de resistência já serem descritas para este patógeno, não se conhecem ainda as estratégias utilizadas na constituição dos híbridos comerciais. Avaliou-se a reação da resistência dos híbridos de pimentão (Capsicum annuum L.) Acuario, Magali R, Nathalie e suas respectivas gerações $F_{2}$ e $F_{3}$, além dos híbridos Amanda, Corteso W208, CPC-6272, Dagmar, Elisa, Magali, Margarita, Monteiro, Quantum e Vivo W205, a Potato virus $Y$, estirpe $m\left(P V Y^{m}\right)$. A inoculação foi realizada a partir de extratos de folhas de pimentão, cv. Magda, previamente infectadas com o vírus. A reação foi expressa em número de plantas resistentes/ suscetíveis. Os híbridos Magali R e Nathalie não apresentaram sintoma sistêmico de mosaico. A resistência dos híbridos comerciais Magali $\mathrm{R}$ e Nathalie a $\mathrm{PVY}^{\mathrm{m}}$ é controlada por um gene dominante, resultante do cruzamento de progenitores resistentes versus suscetíveis. Amanda, Acuario, Corteso W208, Dagmar, Elisa, Margarita, Monteiro, Quantum e Vivo W205, considerados resistentes ao PVY, mostraram-se altamente suscetíveis à estirpe $\mathrm{PVY}^{\mathrm{m}}$. Híbridos considerados resistentes a Pepper mottle virus (PepMoV) são também resistentes à estirpe de $P V Y^{m}$.

Palavras-chave: Capsicum annuum, resistência , potyvirus
\end{abstract}

\section{INTRODUCTION}

The first Brazilian sweet pepper cultivars derived possibly from populations introduced from Spain and Italy in late 20's in Mogi das Cruzes and Suzano city, SP, Brazil (Souza \& Casali, 1984; Peixoto et al., 1995).

The main obstacle for this crop in Brazil occurred in the 50's with the sweet pepper mosaic or virus $Y$ of potato (Potato virus Y - PVY), widely spread in Solanaceae and weed hosts through aphid vectors such as Myzus persicae. The control was first done by insecticides, which was not efficient (Nagai, 1968). Sweet pepper crop expansion in Brazil was only possible using resistant cultivars (Souza \& Casali, 1984). The introduction of resistance to $P V Y$ strains in sweet pepper varieties reduced the losses caused by Potyvirus. It was one the most limiting factor for the susceptible sweet pepper crop.
Sweet pepper is one of the most important vegetables in Brazil. Until the 80's, it was characterized by cultivars such as Casca Dura, Ikeda, Avelar and Agronômico, having a resistant gene which enabled its cultivation. Cultivars of Agronômico lines represented a landmark. In late 80's, a new virus PVY variant named $\mathrm{Y}^{\mathrm{m}}\left(P V Y^{\mathrm{m}}\right)$ overcame the resistance of these cultivars. However, a single and dominant resistance was found in the hybrid PM4 (Nagai, 1993).

Virus transmission and infection can lead to an evolutional process related to the host specialization. Virulence to specific genes in the host can be used to differentiate strains (Northeorte, 1992).

PVY strains infecting sweet pepper are classified by their ability to overcome resistant genes based on differential host reactions. PVY strains were classified by their virulence in differential hosts defined by Gebre

${ }^{1}$ Part of the Thesis of the first author, presented to USP/ESALQ - Piracicaba, SP. 
Selassie et al. (1985), such as: $P(0)$ - common and virulent in Yolo Wonder; $\mathrm{P}(1)$ - virulent in Yolo $\mathrm{Y} ; \mathrm{P}(1-2)$ - virulent in Yolo $Y$ and Florida VR2. The last one also overcomes the Agronômico 10G resistance.

In Brazil, $P V Y^{m}$ isolates are characterized by their capacity to induce mosaic symptoms in two varieties, Magda and Margareth, which had their resistance breakdown (Nagai, 1983). However, Boiteux et al. (1996) reported some studies showing that $\mathrm{PVY}^{\mathrm{m}}$ could represent an isolate of the Potato virus $Y$ strain 1-2.

Many resistant sources found for PVY, Tobacco etch virus (TEV) and Pepper mottle virus (PepMoV) are monogenic and recessive (Palloix \& Kyle, 1995). Three main resistant genes, efficient against different PVY strains, were described in different Capsicum annuum accessions (Kyle \& Palloix, 1997): Yolo $Y$ with recessive gene pvr2 ${ }^{1}$ and Criollo de Morelos 334 with recessive gene pvr5 are resistant to PVY-0; $C$. annuum Flórida VR2 with recessive gene pvr2 ${ }^{2}$ resistant to PVY-0 and PVY1, and Criollo de Morelos 334 with dominant gene Pvr4 resistant to all PVY strains. Some of these resistance genes are specific to some strain, while others had multiple resistance to many related Potyvirus.

In the 90's, occurred many changes due to introduction of new hybrids with higher commercial quality, but most of them susceptible to PVY. At that time, the hybrid Magali $R$ became the leader of the Brazilian sweet pepper market due to its fruit quality associated to its resistance to PVY. Nathalie hybrid, Myr-10 and Myr29 were also highlighted, however with lower fruit quality, but also resistant to PVY. These hybrids and cultivars were grown in large scale for several years and regions and showed resistance durability for the $\mathrm{PVY}^{\mathrm{m}}$ control.

The development of sweet pepper cultivars genetically resistant to Potyvirus is one of the most practical, inexpensive and environmentally safe way to reduce losses caused by this group of viruses.

This study aimed to evaluate sweet pepper hybrids and cultivars reaction to $P V Y^{m}$ as well to elucidate the hybrid genealogical strategy used by seed companies.

\section{MATERIAL AND METHODS}

The experiment was carried out in Piracicaba, SP, Brazil. Resistance reaction to $\mathrm{PVY}^{\mathrm{m}}$ was determined in the following commercial sweet pepper hybrids: Acuario (Asgrow), Magali R (Agroflora/Sakata), Nathalie (Rogers/ Novartis Seed), and their respective $F_{2}$ and $F_{3}$ generations, and the following hybrids and cultivars: Amanda (Agroflora/Sakata), Corteso W208 (Western Seed), CPC-6272, Dagmar (Hortec), Elisa (Rogers/ Novartis Seed), Magali (Agroflora/Sakata), Margarita (Rogers/Novartis Seed), Monteiro (Asgrow), Quantum (Vilmorin), Vivo W205 (Western Seed). Cv. Magda was used as susceptibility standard and Myr-10 and Myr-29 as proof for resistance to $\mathrm{PVY}^{\mathrm{m}}$. The experiment was done in expanded polystyrene trays of 128 cells containing commercial substrate, in a greenhouse, at room temperature and under continued sprinkle i rrigation.

The virus was firstly obtained from sweet pepper plants of the Paulínia/SP region, with systemic symptom and naturally infected. After filtering in Nicotiana tabacum cv. Samsun NN and N. tabacum cv. Havana 425 they were inoculated in cvs. Magda and Ikeda, suppliers of inoculum for identification. A preliminary test was performed to identify the virus based on the reaction of differential cultivars of sweet pepper varieties: Magda, Agronômico 10G, Avelar, Ikeda, Delray Bell, Florida VR2, Florida VR4, Yolo Wonder and Yolo Y, PI-152225, CM334, Myr-10 and Myr-29, as well CM-ESALQ and CM2258 (Gebre-Selassie et al., 1985; Arteaga \& Ortega, 1986; Marchoux \& Gebre Selassie, 1989; Palloix, 1992; Pasko et al., 1992; Pasko, 1993; Brioso et al., 1996). DAS-ELISA serological test was also used.

Three weeks after inoculation, evaluation of differential cultivars was done through the symptoms, and leaves were collected for the serological test in which commercial polyclonal antiserum was used for PVY (Boehringer Mannheim). Reading was performed at 405 $\mathrm{nm}$ and the values were considered positive when the absorbance value was threefold of the negative control.

The virus was kept and multiplied in 'Magda', pattern of susceptibility to the $\left(P V Y^{m}\right)$ strain. In the resistance tests, the differential cultivars used in the preliminary test that distinguish PVY strains were included.

Plants were mechanically inoculated with leaf extracts of cv. Magda obtained by grinding fresh ones in potassium phosphate buffer $0.02 \mathrm{~mol} \mathrm{~L}^{-1}(\mathrm{pH} \mathrm{7)}$. The leaves to be inoculated were sprayed with carborundum and then the inoculum was applied by rubbing them with extract wetted cotton from infected leaves. Soon after inoculation, the leaves were washed with water to remove inoculum excess (Nagai, 1983). Cotyledonary leaves were inoculated 29 days after sowing and repeated in the third true leaf, 36 days after sowing.

Evaluations were performed 17 and 29 days after the last inoculation, counting the plants based on the presence or absence of visual symptoms. Susceptibility reaction was characterized by the presence of systemic symptoms (mosaic or mottling). Latent infections were proved through inoculation in susceptible control plants of cvs. Magda, Ikeda and Yolo Wonder. Plants showing symptoms were inoculated in N. tabacum cv. Samsun NN and $N$. tabacum $\mathrm{cv}$. Havana 425 to recover the virus.

Data obtained were analyzed by the chi-square test (Ramalho et al., 1995).

\section{RESULTS AND DISCUSSION}

In the preliminary test for virus identification, evaluation was performed three weeks after inoculation 
and identified through the DAS-ELISA test in all differential cultivars showing visual symptoms. In the serological analysis, the positive values were about five times higher than the negative absorbance value obtained from healthy not inoculated plants. The resistant controls Myr-10, Myr-29, and the differentials PI-152225 and CM-334 showed no systemic symptoms after mechanical inoculation with $\mathrm{PVY}^{\mathrm{m}}$, which was confirmed by the serological test. CM-334 presented local lesions in the inoculated areas followed by cotyledon abscission, a typical hypersensitive symptom.

Based on the reaction of Magda, Agronômico 10G, Avelar, Ikeda, Myr-10 and Myr-29 (Table 1), the virus used in this study was classified as a PVY variant named $Y^{\mathrm{m}}\left(P V Y^{\mathrm{m}}\right)$, which breakdown Agronômico, Magda and Margareth resistance in late 80's. Similar results were observed by Brioso et al. (1996). Cook (1961), Nagai \&
Costa (1972), Pahlen \& Nagai (1973), Gebre Selassie et al. (1985), Greenleaf (1986); Arteaga \& Ortega (1986), Marchoux \& Gevre Selassie (1989), Nagai (1993), Pasko (1993) and Brioso et al. (1996) also classified PVY strains infecting sweet pepper based on Capsicum differential reaction in several regions. Results of these authors are shown in Table 1 and compared with data from this work.

Sweet pepper cvs. Yolo Wonder, Yolo $Y$ and Florida VR2 were recommended by Gebre Selassie et al. (1985) to identify PVY strains (0, 1 and 1-2) and for comparison among strains from different regions which suggest that the isolate in this work is similar to strain 12. According to Boiteux et al. (1996), some studies have concluded that $P V Y^{\mathrm{m}}$ represents a Potato virus $Y$ isolate, strain 1-2. Brioso et al. (1996) indicate that $P V Y^{m}$ strain is similar to Potato virus $Y$ isolate named "RJ".

Table 1 - Reaction of Capsicum cultivars, used as differential to the Potato virus Y (PVY), originating from various geographical areas. Piracicaba, SP. 2000.

\begin{tabular}{|c|c|c|c|c|c|c|c|c|c|c|c|c|c|c|c|c|}
\hline \multirow[t]{2}{*}{ Capsicum cultivar } & \multirow[t]{2}{*}{ PepMoV ${ }^{(1)}$} & \multirow[t]{2}{*}{ PepMoV ${ }^{(2)}$} & \multicolumn{3}{|c|}{$\begin{array}{l}\text { Strains } \\
P V Y^{(3)}\end{array}$} & \multicolumn{3}{|c|}{$\begin{array}{l}\text { Strains } \\
P V Y^{(4)}\end{array}$} & \multicolumn{3}{|c|}{$\begin{array}{c}\text { Strains } \\
P \vee Y^{(2)}\end{array}$} & \multirow{2}{*}{$\frac{P \vee Y^{(5)}}{R J}$} & \multicolumn{3}{|c|}{$\begin{array}{l}\text { Strains } \\
P V Y^{(6)}\end{array}$} & \multirow{2}{*}{$\frac{P V Y^{(7)}}{m}$} \\
\hline & & & 0 & 1 & $1-2$ & 0 & 1 & $1-2$ & 0 & 1 & $1-2$ & & $f$ & $\mathrm{n}$ & $\mathrm{m}$ & \\
\hline Agronômico 10* & & IR & & & & - & - & + & - & - & - & + & - & $\mathrm{T}$ & + & + \\
\hline Agronômico 8 & & & - & - & + & - & - & $\mathrm{RH}$ & & & & + & - & $\mathrm{T}$ & + & \\
\hline Avelar ${ }^{*}$ & - & & - & + & + & & & & & & & & & & & + \\
\hline Casca Dura & & & & & & & & & & & & + & & & + & \\
\hline Casca Grossa & & & - & + & + & & & & & & & & + & + & & \\
\hline CM 2258* & & & & & & & & & & & & & & & & + \\
\hline CM 334* & & - & & & & & & & - & - & - & & & & & - \\
\hline Delray Bell* & - & IR & & & & - & - & + & - & - & - & & & & & + \\
\hline Florida VR2* & + & + & - & - & + & - & - & + & - & - & + & & & & & + \\
\hline Florida VR4* & & IR & & & & & & & - & - & - & & & & & + \\
\hline Híbrido PM4 & & & & & & & & & & & & & & & - & \\
\hline lkeda* & & & - & + & + & - & - & + & & & & + & $\mathrm{T}$ & $\mathrm{T}$ & & + \\
\hline Magda* & & & & & & & & & & & & + & & & & + \\
\hline Margareth & & & & & & & & & & & & + & & & & \\
\hline Moura & & & - & + & + & - & $\mathrm{RH}$ & + & & & & & $\mathrm{T}$ & $\mathrm{T}$ & & \\
\hline Myr10* & & & & & & & & & & & & - & & & & - \\
\hline Myr29* & & & & & & & & & & & & - & & & & - \\
\hline PI 152225* & $+\mathrm{T}$ & - & + & + & & $\mathrm{RH}$ & - & + & - & - & - & & & & & - \\
\hline PI 159236 & - & - & - & + & & - & $\mathrm{RH}$ & + & - & - & - & & & & & \\
\hline PI 201232 & & & & & & & & & & & & + & & & & \\
\hline PI 264281 & + & & - & - & + & & & & & & & & - & + & & \\
\hline Puerto Rico Wonder & & & - & + & + & - & - & - & & & & + & + & + & + & \\
\hline SC 46252 & + & & & & & & & & & & & & & & & \\
\hline SCM 334 & & + & - & - & - & - & - & $\mathrm{RH}$ & - & + & + & & & & & \\
\hline Serrano de veracruz & & IR & - & - & - & - & - & - & - & - & - & & & & & \\
\hline Yolo A, B ou L, ECW & & + & & & & & & & + & + & + & & & & & \\
\hline Yolo Wonder* & + & & + & + & + & + & + & + & & & & + & + & + & & + \\
\hline Yolo Y (RPD10)* & + & + & - & + & + & - & + & + & - & + & + & & + & + & & + \\
\hline
\end{tabular}


Virulence variability of PVY strains as for the reactions in Capsicum differential cultivars was reported by Arteaga \& Ortega (1986), Pasko et al. (1995) and Arteaga et al. (1997), showing the need for a better identification of such strains.

Evaluations carried out 17 and 29 days after inoculation to determine hybrid resistance reactions showed the same result. At the $29^{\text {th }}$ day after inoculation, Acuario hybrid and its $F_{2}$ generation presented generalized symptoms of mosaic in the leaves, showing no resistance to $\mathrm{PVY}^{\mathrm{m}}$, although described as resistant to European PVY strains (Table 2). Magali $R$ and Nathalie had no infection systemic symptoms (Table 2), however they presented necrotic local lesions on cotyledons inoculated with $\mathrm{PVY}^{\mathrm{m}}$ as well in their respective $F_{2}$ and $F_{3}$ generations. The lesions were small and followed by cotyledon abscission, similar to the hypersensitivity response. Hypersensitivity is a local reaction, restricted to cells invaded by the pathogen or adjacent ones. The "localization" is considered a resistance response to the virus (Fraser, 1990). This reaction can avoid virus dissemination from the inoculation local to other plants parts, limiting its replication (Ponz \& Bruening, 1986).

In most incompatible interactions, hypersensitivity response is controlled by resistant genes (Berger et al., 1999). Such mechanism is probably associated to Magali $R$ and Nathalie hybrid resistances, considered infection-free by the DAS-ELISA test and inoculation in susceptible cultivars. Similar results were observed by Dogimont et al. (1996) in CM334 inoculated with PVY strain 1-2, which induced hypersensitive reaction. This result suggests that the resistance is controlled by a dominant gene probably derived from CM-334. According to Ponz \& Bruening (1986), the ability to develop necrotic local lesions seems to be controlled by only one dominant gene. Fraser (1990) suggests that the interaction between host and the virus "Iocalization" is a phenomena associated with dominant resistant genes.

Segregation data on the reaction to $\mathrm{PVY}^{\mathrm{m}}$ (Table 2 ) were not significant $\left(\chi^{2}<\chi^{2} 0.05\right)$. Resistance genetic analysis of Magali $R$ and Nathalie hybrids inoculated with $P V Y^{m}$ was carried out in $F_{2}$ and $F_{3}$ generations. Reaction of $F_{2}$ generation had the ratio 3 resistant plants : 1 susceptible plant, indicating an independent segregation for a single dominant gene. Among eleven Magali $\mathrm{R} \mathrm{F}_{3}$ progenies and four Nathalie $\mathrm{F}_{3}$ progenies, the segregation ratio observed for resistance to $\mathrm{PVY}^{\mathrm{m}}$ (resistance and susceptibility ratio) was $0: 1,1: 0$ and $3: 1$.

Segregations observed for $\mathrm{F}_{3}$ progenies were consistent with the results obtained from $F_{2}$. In many

Table 2 - Segregation data of the reaction of the commercial pepper hybrids and their generations $F_{2}$ and $F_{3}$ to the Potato virus Y, (PVYm). Piracicaba, SP. 2000.

\begin{tabular}{|c|c|c|c|c|c|c|}
\hline \multirow{2}{*}{ Hybrid } & \multirow{2}{*}{ Generation } & \multicolumn{2}{|c|}{$\mathrm{N}^{\circ}$ of plant } & \multirow{2}{*}{$\begin{array}{l}\text { Ratio* } \\
\text { (R:S) }\end{array}$} & \multirow{2}{*}{$\chi^{2}$} & \multirow{2}{*}{$P$} \\
\hline & & $R$ & $S$ & & & \\
\hline \multirow[t]{2}{*}{ Acuario } & $F_{1}$ & 0 & 10 & $0: 1$ & - & 1,00 \\
\hline & $\mathrm{F}_{2}$ & 0 & 68 & $0: 1$ & - & 1,00 \\
\hline \multirow[t]{13}{*}{ Magali R } & $\mathrm{F}_{1}$ & 67 & 0 & $1: 0$ & - & 1,00 \\
\hline & $\mathrm{F}_{2}$ & 453 & 142 & $3: 1$ & 0,41 & 0,52 \\
\hline & $\mathrm{F}_{3}$ & 28 & 0 & $1: 0$ & - & 1,00 \\
\hline & $\mathrm{F}_{3}$ & 28 & 10 & $3: 1$ & 0,04 & 0,85 \\
\hline & $\mathrm{F}_{3}$ & 19 & 1 & $1: 0$ & 0,05 & 0,82 \\
\hline & $\mathrm{F}_{3}$ & 15 & 8 & $3: 1$ & 1,17 & 0,28 \\
\hline & $\mathrm{F}_{3}$ & 9 & 4 & $3: 1$ & 0,23 & 0,63 \\
\hline & $\mathrm{F}_{3}$ & 24 & 3 & $3: 1$ & 2,77 & 0,10 \\
\hline & $\mathrm{F}_{3}$ & 29 & 0 & $1: 0$ & - & 1,00 \\
\hline & $\mathrm{F}_{3}$ & 10 & 3 & $3: 1$ & 0,03 & 0,87 \\
\hline & $\mathrm{F}_{3}$ & 0 & 13 & $0: 1$ & - & 1,00 \\
\hline & $\mathrm{F}_{3}$ & 43 & 13 & $3: 1$ & 0,10 & 0,76 \\
\hline & $\mathrm{F}_{3}$ & 43 & 21 & $3: 1$ & 2,08 & 0,15 \\
\hline \multirow[t]{6}{*}{ Nathalie } & $F_{1}$ & 46 & 0 & $1: 0$ & - & 1,00 \\
\hline & $\mathrm{F}_{2}$ & 496 & 161 & $3: 1$ & 0,09 & 0,77 \\
\hline & $\mathrm{F}_{3}$ & 22 & 0 & $1: 0$ & - & 1,00 \\
\hline & $\mathrm{F}_{3}$ & 14 & 2 & $3: 1$ & 1,33 & 0,25 \\
\hline & $\mathrm{F}_{3}$ & 20 & 0 & 1:0 & - & 1,00 \\
\hline & $\mathrm{F}_{3}$ & 0 & 15 & $0: 1$ & - & 1,00 \\
\hline
\end{tabular}

${ }^{*}$ Hypothesized segregation ratio of resistant $(R)$ to susceptible $(S)$ plants. 
cases, resistance to virus is under a simple genetic control with a single dominant gene (Fraser, 1990), thus being possible to be evaluated in terms of quality, either by virus presence or absence. In these cases, the genetic analysis was simple and resistance and susceptibility segregated in accordance to Mendelian pattern, indicating a clear dominance inheritance.

In Capsicum, three genetic patterns of resistance to PVY strains were found. A recessive monogenic resistance model suggested by Cook \& Anderson (1960) and Cook (1963), and an oligogenic theory combining three independent genes, one dominant and two recessive, proposed by Nagai \& Costa (1972). A dominant monogenic resistance was described in Serrano de Vera Cruz (C. annuum L.) by Palloix (1992), Pasko et al. (1992) and Dogimont et al. (1996). Our results agree with those of the last authors.

Cvs. Myr-10 and and Myr-29, CM-334 and PI152225 strains and CPC-6272 hybrid showed no systemic infection symptom to $\mathrm{PVY}^{\mathrm{m}}$ during evaluation. This result was confirmed through inoculation in susceptible cultivars. However, it was observed that Amanda, Corteso W208, Dagmar, Elisa, Magali, Margarita, Monteiro, Quantum and Vivo W205 hybrids and cvs. Agronômico 10G, Delray Bell, Florida VR2, Florida VR4, Ikeda, Magda, Yolo Wonder and Yolo $Y$ were highly susceptible to $P V Y^{m}$ (Table 3 ). The virus from these susceptible hybrids was recovered in tabaco Samsum NN and Havana 425.

Resistance of cvs. Myr-10 and Myr-29 developed by Hiroshi Watanabe seem to be inherited as a dominant gene since it was derived originally from a crossing PM4 hybrid with susceptible cv. Margareth. Possibly, Magali $\mathrm{R}$ hybrid dominant resistance has the same origin. In general, the dominant resistance to $P V Y^{m}$ may be derived from the Pvr4 gene. CPC-6272 hybrid behaved like Myr10 and Myr-29.

Criollo de Morelos 334 presented local lesions followed by cotyledon abscission. CM-334 resistance was described as monogenic and dominant by Palloix (1992), Pasko et al. (1992) and Boiteaux et al. (1996). According to Dogimont et al. (1996), CM-334 strain resistance is controlled by a dominant gene named Pvr4 which provides resistance to all PVY and PepMoV strains, and they only observed the lesions when inoculated with PVY 1-2. Thus, the resistant differentials were as efficient to $\mathrm{PVY}^{\mathrm{m}}$ as to $1-2$ strain.

Resistant hybrids first selected to PVY and PepMoV strains developed in the USA was also resistant to Brazilian $\mathrm{PVY}^{\mathrm{m}}$, indicating that resistance to this virus may be controlled by the Pvr4 gene, which probably is resistant to other Potyvirus.

Hybrid genealogy has been kept confidential by private vegetable growers. These hybrid resistance descriptions to PVY are generic, showing no specific resistance to each strain. In different species of the
Table 3 - Hybrids, cultivars and lines of Capsicum reaction to the Potato virus $Y,\left(P V Y^{m}\right)$. Piracicaba, SP. 2000.

\begin{tabular}{|c|c|c|}
\hline \multirow{2}{*}{ Hybrid, cultivar and line } & \multicolumn{2}{|c|}{$\mathrm{N}^{\circ}$ of plant* } \\
\hline & $\mathrm{R}$ & $\mathrm{s}$ \\
\hline Agronômico $10 \mathrm{G}$ & 0 & 10 \\
\hline Amanda & 2 & 97 \\
\hline CM-2258 & 2 & 42 \\
\hline CM-334 & 4 & 0 \\
\hline CPC-6272 & 6 & 0 \\
\hline CM-ESALQ & 2 & 73 \\
\hline Corteso W208 & 0 & 14 \\
\hline Dagmar & 0 & 57 \\
\hline Delray Bell & 0 & 10 \\
\hline Elisa & 0 & 55 \\
\hline Florida VR2 & 0 & 10 \\
\hline Florida VR4 & 0 & 10 \\
\hline Ikeda & 1 & 63 \\
\hline Magali & 0 & 48 \\
\hline Magda & 0 & 34 \\
\hline Margarita & 0 & 51 \\
\hline Monteiro & 0 & 22 \\
\hline Myr-10 & 59 & 0 \\
\hline Myr-29 & 66 & 0 \\
\hline PI 152225 & 80 & 0 \\
\hline Quantum & 1 & 44 \\
\hline Vivo W205 & 0 & 31 \\
\hline Yolo Wonder & 0 & 51 \\
\hline Yolo Y & 0 & 10 \\
\hline
\end{tabular}

*Numbers of resistant (R) and susceptible (S) plants

same genera, the resistance sources to some species of Potyvirus can be the same or specific to different strains of the same virus. In many examples, resistance to Potyviridae is specific to each particular strain and for this reason, a gene can be resistant to a certain strain but totally inefficient to another strain of the same virus. Many European sweet pepper hybrids resistant to PVY strains are susceptible to $\mathrm{PVY}^{\mathrm{m}}$

Decades of Myr-10, Myr-29, Magali R and Nathalie cultivation have shown that their resistance has been stable and possibly due to the Pvr4 gene. Cultivars decline and their replacement by hybrids in Brazil may not explained only by outbreak of more aggressive PVY strains. There is a growing market preference for hybrids with better fruit qualities, yield and more disease resistance profile.

It is very important that seed companies know hybrid resistance to $\mathrm{PVY}^{\mathrm{m}}$ in their pepper breeding programs. New resistant parental lines can be developed by resistant hybrid breakdown to be used in new crossing combinations. 


\section{REFERENCES}

ARTEAGA, M.L.; ANDRÉS, M.A.; ORTEGA, R.G. New Potato virus $Y$ pathotype in pepper. Capsicum and Eggplant Newsletter, v.16, p.8586, 1997

ARTEAGA, M.L.; ORTEGA, R.G. Biological characterization of PVY as isolated from pepper in Spain. In: MEETING ON GENETICS AND BREEDING ON CAPSICUM AND EGGPLANT, 6., Zaragoza, 1986. Proceedings Zaragoza: Eucarpia, 1986. p.183-188.

BERGER, J.; HARFOLD, M.; BERGER, S.; BUCHENAUER, H. Cytological responses of susceptible and extremely resistant potato plants to inoculation with Potato virus Y. Physiological and Molecular Plant Pathology, v.55, p.143-150, 1999.

BOITEUX, L.S.; CUPERTINO, F.P.; SILVA, C.; DUSI, A.N.; MONTE-NESHICH, D.C. Resistance to Potato virus $Y$ (pathotype 1-2) in Capsicum annuum and Capsicum chinense is controlled by two independent major genes. Euphytica, v.87, p.53-58, 1996

BRIOSO, P.S.T.; FERREIRA, M.A.; OLIVEIRA, D.E. Potato virus Y identificação de uma estirpe infectando naturalmente pimentão (Capsicum annuum) e fonte de resistência. Fitopatologia Brasileira, v.21, p.226235, 1996

COOK, A.A. A mutation for resistance to Potato virus $y$ in pepper Phytopathology, v.51, p.550-552, 1961.

COOK, A.A. Genetics of response in pepper to three strains of Potato virus $Y$. Phytopathology, v.53, p.720-722, 1963.

COOK, A.A.; ANDERSON, C.W. Inheritance of resistance to Potato virus $Y$ derived from two strains of Capsicum annuum. Phytopathology, v.50, p.73-75, 1960.

DOGIMONT, C.; PALLOIX, A.; DAUBZE, A.M.; MARCHOUX, G.; SELASSIE K.G.; POCHARD, E. Genetic analysis of broad spectrum resistance to Potyviruses using doubled haploid lines of pepper (Capsicum annuum L.) Euphytica, v.88, p.231-239, 1996.

FRASER, R.S.S. The genetics of resistance to plant viruses. Annual Review of Phytopathology, v.28, p.179-200, 1990

GEBRE-SELASSIE, K.; MARCHOUX, G.; DELECLLE, B.; POCHARD, E. Variabilité naturelle des souches du virus $Y$ de la pomme de terre dans les cultures de piment du sud-est de la France. Caractérisation et classification en pathotypes. Agronomie, v.5, p.621-630, 1985

GREENLEAF, W.H. Pepper breeding. In: BASSET, M.J. (Ed.) Breeding vegetables crops. Westport: AVI Publishing, 1986. p.67-133.

KYLE, M.M.; PALLOIX, A. Proposed revision of nomenclature for Potyvirus resistance genes in Capsicum. Euphytica, v.97, p.183-188, 1997.

MARCHOUX, G.; GEBRE-SELASSIE, K. Variabilité des virus chez les solanées maraîchères: consequence pour la recherche de méthodes de lutte. Phytoma, v.404, p.49-52, 1989.

NAGAI, $\mathrm{H}$. Melhoramento de pimentão (Capsicum annuum L.) visando resistência ao vírus Y. Horticultura Brasileira, v.1, p.3-9, 1983.

NAGAI, H. Obtenção de variedades de pimentão resistente ao mosaico. Bragantia, v.27, p.311-354, 1968.
NAGAI, H. Pimentão, pimenta-doce e pimentas. In: FURLANI, A.M.C.; VIÉGAS, G.P. (Ed.) O melhoramento de plantas no Instituto Agronômico. Campinas: IAC, 1993. v.1, p.276-294.

NAGAI, H.; COSTA, A.S. Four new pepper varieties resistant to virus $Y$ in Brasil. In: MEETING ON GENETICS AND BREEDING ON CAPSICUM, 1.,Turin, 1972. Proceedings. Turin: Eucarpia, 1972. p.283-287.

NORTHCOTE, E.N.F. Potyvirus taxonomy potyviroses that affect solanaceous crops. In: BARNETT, O.W. (Ed.) Potyvurus taxonomia. New York: Springer-Verlag. Archives of virology, supp. 5, p.221-222, 1992.

PAHLEN, A.V.D.; NAGAI, H. Resistencia del pimiento (Capsicum spp.) a estirpes predominantes del virus ' $Y$ ' de la papa en Buenos Aires, el N.O. argentino y en el centro sur de Brasil. Revista de Investigaciones Agropecuarias. Serie 5: Patologia Vegetal, v.10, p.109-116, 1973.

PALLOIX, A. Disease of pepper and pespectives for genetic control. In: EUCARPIA MEETING ON GENETICS AND BREEDING ON CAPSICUM AND EGGPLANT, 8., Rome, 1992. Proceedings. Rome: Eucarpia, 1992. p.120-126.

PALLOIX, A.; KYLE, M.M. Proposal revision of gene nomenclature for potyvirus resistance genes in Capsicum sp. Capsicum and Eggplant Newsletter v,14, p.26-29, 1995

PASKO, P. A study on pepper resistance to potato virus $\mathrm{Y}$ (PVY). Zaragoza: IAMZ, 1993. 112p.

PASKO, P: ARTEAGA, M. : ORTEGA, R G. Different kinds of reactions to PVY 1-2 in Capsicum annuum L. cv. 'SCM 3334'. In: MEETING ON GENETICS AND BREEDING ON CAPSICUM AND EGGPLANT, 8., Rome, 1992. Proceedings. Rome: Eucarpia, 1992, p.153-156.

PASKO, P.; ARTEAGA, M.L.; ORTEGA, R.G. A citoplasmically determined resistence to potato virus $Y(P V Y)$ in Capsicum annuum L. cV. Puerto Rico Wonder. In: MEETING ON GENETICS AND BREEDING ON CAPSICUM AND EGGPLANT, 9., Budapest, 1995. Proceedings. Budapest: Eucarpia, 1995. p.169-172.

PEIXOTO, J.R.; MALUF, W.R.; CAMPOS, V.P. Avaliação de genótipos de pimentão quanto à resistência a Meloydogyne incognita (raça 2) e a Meloydogyne javanica. Horticultura Brasileira, v.13, p.154-158, 1995.

PONZ, F.; BRUENING, G. Mechanisms of resistance to plant viruses. Annual Review of Phytopathology, v.24, p.355-381, 1986.

RAMALHO, M.; SANTOS, J.B.; PINTO, C.B. Genética na Agropecuária. 4.ed. São Paulo: Globo, 1995. 359p.

SOUZA, R.J. de; CASALI, V.W.D. Cultivares de pimentão e pimenta. Informe Agropecuário, v.10, p.14-18, 1984

Received February 16, 2001 